\title{
Peningkatan Nilai Tambah Biji Durian (Durio Zibethinus) Dan Biji Rambutan (Nephelium Lappaceum) Menjadi Keripik
}

\author{
Astrilia Damayanti ${ }^{1}$, Riana Defi Mahadji Putri ${ }^{2}$, Megawati ${ }^{3}$, \\ Desy Hikmatul Siami ${ }^{4}$, Zulfi Fitriani ${ }^{5}$ \\ 1,3,4,5Jurusan Teknik Kimia, Fakultas Teknik, Universitas Negeri Semarang, Kampus UNNES Sekaran \\ Gunungpati, Semarang 50229, Indonesia \\ 2Jurusan Teknik Elektro, Fakultas Teknik, Universitas Negeri Semarang, Kampus UNNES Sekaran Gunungpati, \\ Semarang 50229, Indonesia \\ E-mail: astrilia.damayanti@mail.unnes.ac.id
}

\begin{abstract}
Abstrak
Tujuan kegiatan ini adalah untuk memperkenalkan teknologi pangan kepada ibu-ibu PKK RT03/RW03, Kelurahan Ngijo, Kecamatan Gunungpati, Semarang dengan memanfaatkan biji Durian (Durio zibethinus) dan biji Rambutan (Nephelium lappaceum) sebagai keripik. Target luaran yang diharapkan antara lain masyarakat dapat berwirausaha sehingga kesejahteraan keluarga dapat ditingkatkan. Hasil dari program pengabdian masyarakat yang telah dilakukan ini adalah sebagai berikut: aspek penerapan iptek produk pangan dipandang sangat efektif untuk membangun kemandirian masyarakat yang berbasis potensi lokal yakni pemanfaatan biji durian dan biji rambutan, dan aspek manfaat yang dihasilkan dari program ini sangat besar yaitu meningkatkan kesadaran masyarakat untuk memanfaatkan potensi pohon Durian dan Rambutan terutama bijinya untuk dibuat menjadi keripik, meningkatnya pengetahuan dan keterampilan masyarakat bidang pengolahan biji durian dan rambutan untuk dibuat keripik serta menumbuhkan motivasi berwirausaha khususnya di RT03/RW03, Kelurahan Ngijo, Kecamatan Gunungpati, Semarang. Sehingga masyarakat menjadi lebih produktif dan memiliki wawasan lebih dalam memanfaatkan nilai tambah biji durian.

Kata Kunci: keripik, biji durian dan rambutan, PKK RT03/RW03, Kelurahan Ngijo, Kecamatan Gunungpati, Semarang

\section{Abstract}

The purpose of this activity is to introduce food technology to the ladies of PKK RT03/RW03, Ngijo, Gunungpati, Semarang by using Durian (Durio zibethinus) seeds and Rambutan (Nephelium lappaceum) seeds as chips. Expected output targets include the community can entrepreneurship so that family welfare can be improved. The results of community service programs that have been done are as follows: aspects of the application of food product science and technology is considered very effective to build community self-reliance based on local potency that is utilization of durian seeds and Rambutan seeds, and benefit aspect generated from this program is very big that is raising public awareness to exploit potency Durian and Rambutan tree, especially the seeds to be made into chips, the increasing knowledge and skills of the community of durian and rambutan seeds processing to be made chips and cultivate entrepreneurship motivation, especially in RT 03/RW03, Ngijo, Gunungpati, Semarang.
\end{abstract}


Keywords: chips, Durian and Rambutan seeds, PKK group in RT 03 / RW03, Ngijo Village, Gunungpati District, Semarang

\section{PENDAHULUAN}

Durian (Durio zibethinus) adalah salah satu buah pada daerah tropis yang sangat populer di Indonesia. Buah dengan julukan The King of fruits ini termasuk dalam family Bombacaceae. (Djaeni \& Prasetyaningrum, 2010). Sampai sekarang jumlah spesies yang sudah ditemukan sebanyak 27 jenis tanaman durian, diantaranya ialah Durio kutejensis, D. oxyleyanus, D. dulcis, $D$. grandifloras, $D$. testudinarium, dan D. zibhetinus Murr, dan yang buahnya paling enak ialah $D$. zibethinus (Harmiatun, Sunarto, \& Gultom, 2018). Bagian buah durian selama ini yang umum dikonsumsi adalah bagian salut buah atau dagingnya sedangkan bagian lainnya sebatas menjadi limbah. Persentase berat bagian ini termasuk rendah hanya $20-35 \%$. Hal ini berarti kulit (60-75\%) dan biji (5-15\%) belum termanfaatkan secara maksimal. Biji mentah durian yang mengandung asam lemak siklopropena tidak dapat dimanfaatkan secara langsung karena beracun. Sedangkan kandungan yang ada pada biji durian ialah 51,5\% air, 46,2\% karbohidrat, 2,5\% protein dan 0,2\% lemak. Kandungan karbohidrat inilah yang dapat dimanfaatkan sebagai makanan kering seperti keripik (Djaeni \& Prasetyaningrum, 2010).

Potensi lokal yang layak dikembangkan juga adalah rambutan. Rambutan (Nephelium lappaceum) adalah tanaman tropis yang tergolong ke dalam suku lerak-lerakan atau Sapidance. Sejauh ini pemanfaatan rambutan hanya sekedar pada daging buahnya. Kulit dan biji belum dimanfaatkan secara maksimal karena sebagian masyarakat menganggap itu bagian dari limbah buah rambutan. Sedangkan kandungan yang terdapat pada biji rambutan ialah 11,9-14,1\% protein, 2,8-6,6\% serabut kasar, 37,1-38,9\% lemak kasar (ekstrak eter petroleum) dan 2,6-2,9\% abu pada dasar berat kering(Augustin \& Chua, 1988). Nilai tambah pada biji rambutan ini dapat dilaksanakan dengan memanfaatkan teknologi pangan yang dapat mengubah biji rambutan menjadi produk bermanfaat seperti keripik sebagai cemilan dengan rasa yang khas.

Pemerintah kota Semarang meluncurkan program percepatan penanggulangan kemiskinan (PPK) guna untuk mengurangi angka kemiskinan, dengan target dapat menekan angka kemiskinan sekitar $2 \%$ pertahun. Dalam menerapkan program tersebut Pemerintahan kota Semarang bekerjasama dengan perguruan tinggi di kota Semarang sebagai pelaksana program. Berdasarkan koordinasi Bappeda kota Semarang, pada pelakasanaan Program Gerdu Kempling tahun IV (2014), Universitas Negeri Semarang ditunjuk untuk menangani 4 kelurahan yaitu: Sukorejo, Kalisegoro, Mangunsari dan Ngijo di Kecamatan Gunungpati tersebut (Rosidah, Henry, \& Sunyoto, 2015).

Berdasarkan Tabel 1 dapat diketahui bahwa potensi unggulan hasil pertanian yang ada di kelurahan ngijo adalah Durian dan Rambutan. Menurut ketua PKK RT03/RW03, Kelurahan Ngijo, Kecamatan Gunungpati, Semarang Ibu Yayuk, mengungkapkan adanya keinginan dari ibu-ibu PKK untuk mendapatkan ketrampilan yang dapat memberi bekal berwirausaha. Salah satu bentuk ketrampilan tersebut adalah memanfaatkan dan meningkatkan ketrampilan dalam membuat makanan dan minuman yang sehat, sehingga bila nantinya akan dikembangkan sebagai wirausaha masih memiliki nilai efektif dan ekonomis.

Untuk itu, kami dengan tim berkeinginan melakukan pendampingan pada masyarakat di lingkungan ibu-ibu PKK RT03/RW03, Kelurahan Ngijo, Kecamatan Gunungpati, Semarang untuk menumbuhkan kreativitas wirausaha memanfaatkan biji durian dan rambutan sebagai keripik 
yang dikemas secara menarik, dengan tujuan kegiatan ini adalah untuk memperkenalkan teknologi pangan kepada ibu-ibu PKK RT03/RW03, Kelurahan Ngijo, Kecamatan Gunungpati, Semarang dengan memanfaatkan biji Durian (Durio zibethinus) dan biji Rambutan (Nephelium lappaceum) sebagai keripik.

Tabel 1. Potensi Unggulan pertanian, peternakan, perikanan

\begin{tabular}{lll}
\hline No & Kelurahan & \multicolumn{1}{c}{ Potensi Unggulan } \\
\hline 1 & Sukorejo & $\begin{array}{l}\text { Hasil pertanian: singkong, pisang, rambutan, mangga. } \\
\text { Home industry: hasil panen banyak yang belum diolah/dijual langsung. }\end{array}$ \\
\hline 2 & Kalisegoro & $\begin{array}{l}\text { Hasil pertanian/peternakan: jahe, singkong, talas, pisang, durian, rambutan, } \\
\text { mangga, itik. } \\
\end{array}$ \\
& & $\begin{array}{l}\text { Home industry: pengolahan jahe, hasil panen masih banyak yang belum } \\
\text { diolah. }\end{array}$ \\
\hline 3 & Mangunsari & Hasil pertanian/perikanan: kacang tanah, singkong, pisang, durian, \\
& & rambutan, mangga, ikan lele. \\
& Home industry: hasil panen banyak yang belum diolah/dijual langsung \\
\hline 4 & Ngijo & Hasil pertanian/peternakan: singkong, talas, suweg, pisang, durian, \\
& rambutan, mangga, ternak sapi. \\
& Home industry: hasil panen banyak yang belum diolah/dijual langsung
\end{tabular}
Sumber: (Rosidah et al., 2015)

\section{METODE PELAKSANAAN}

Berdasarkan permasalahan yang dihadapi mitra, maka perlu diterapkan unit percontohan, kajian tentang aspek sosial dan ekonomi sehubungan dengan penerapan teknologi pembuatan keripik biji durian dan rambutan yang sekaligus sebagai sarana latihan dan praktek bagi para ibu-ibu PKK RT03/RW03, Kelurahan Ngijo, Kecamatan Gunungpati, Semarang.

Kegiatan ini dilaksanakan pada bulan Mei-Oktober 2019 yang terbagi dalam tahap survei dan analisis lapangan, percobaan kembali, penyuluhan, demonstrasi, dan praktek. Berdasarkan hasil survei dan analisis lapangan yang telah dilakukan maka dibutuhkan penyuluhan upaya untuk meningkatkan nilai tambah pada biji rambutan dan biji durian. Sebelum dilakukan penyuluhan kepada masyarakat dilakukan uji coba kembali untuk menghasilkan produk yang lebih baik

Penyuluhan dimulai dengan membagikan diagram alir pembuatan keripik dari biji durian dan rambutan yang diberikan ke ibu-ibu disajikan pada Gambar 1 dan Gambar 2. Demonstrasi pengolahan kemudian dilanjutkan dengan menjelaskan langkah-langkah pengolahan produk sebagai berikut:

a. Pengolahan keripik biji durian

Tahap awal pemilihan biji, proses pencucian, perebusan dengan garam, pengupasan kulit terluar, pengirisan, perendaman dengan kapur sirih, pencucian ulang dan penggorengan. Tahap hari ialah pemberian bumbu tambur sesuai selera.

b. Pengolahan keripik biji rambutan

Tahap awal pemilihan biji, proses pencucian, penyangraian biji, pemipihan biji, penjemuran, penggorengan dan pemberian bumbu.

Langkah-langkat tersebut disajikan dalam diagram alur pada Gambar 1 dan Gambar 2. 
Biji durian

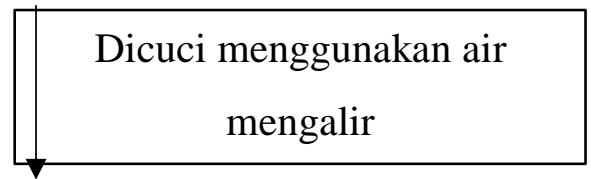

Biji durian bersih

$\downarrow \begin{gathered}\text { Direbus selama 10-15 } \\ \text { menit }\end{gathered}$

Biji durian menjadi lunak

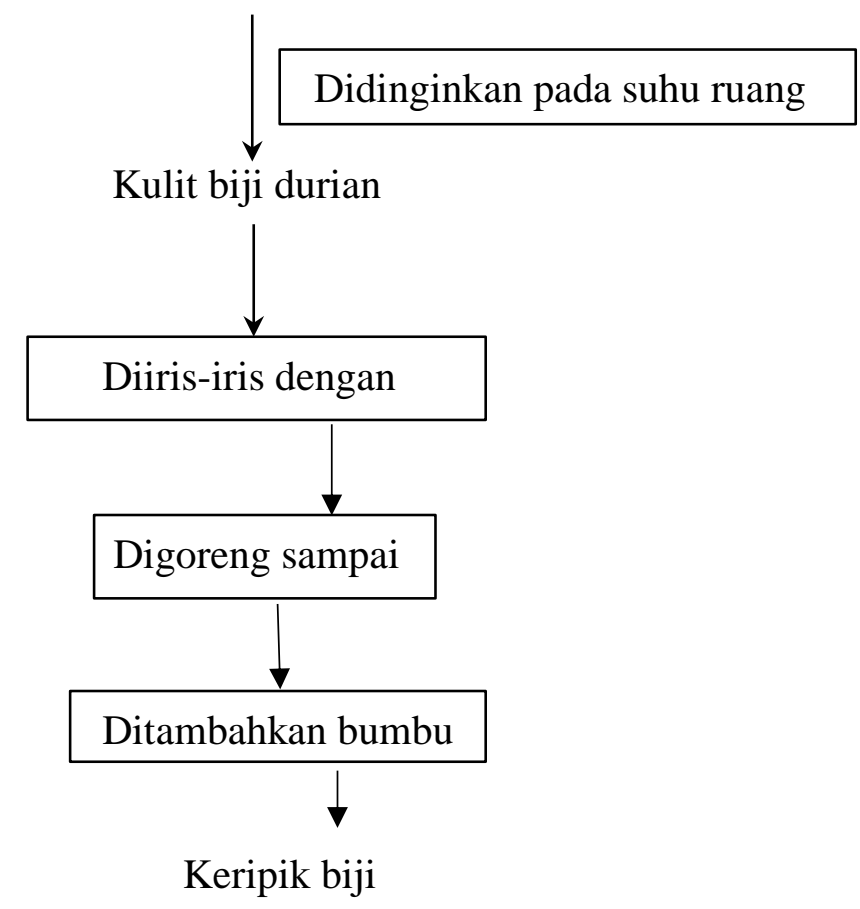

Gambar 1. Diagram Alur Pembuatan Keripik Biji Durian 
Biji rambutan

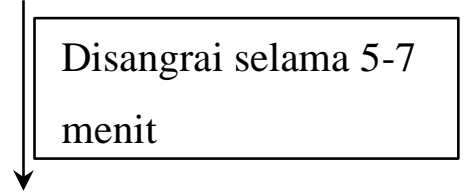

Kulit biji rambutan dikupas

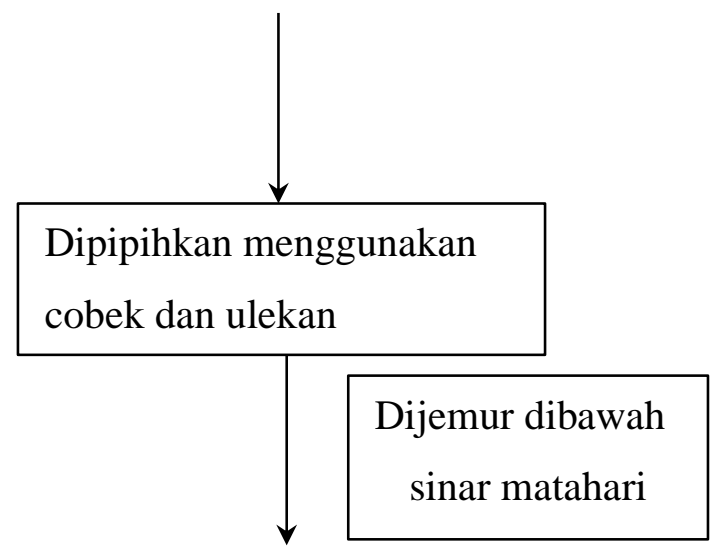

Biji rambutan kering

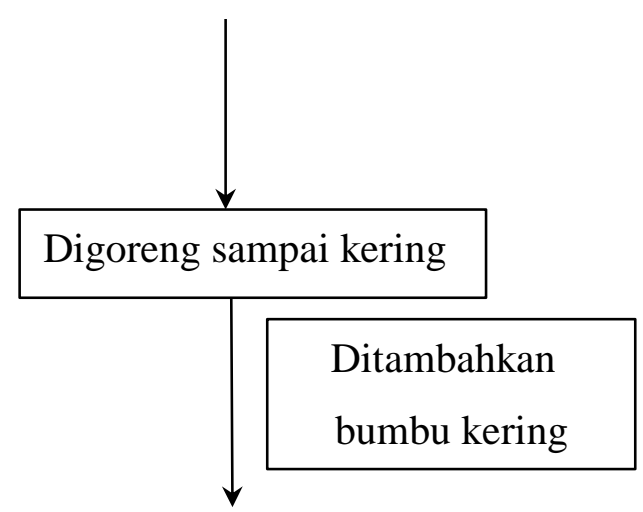

Keripik biji rambutan

\section{Gambar 2. Diagram Alur Pembuatan Keripik Biji Rambutan}

\section{HASIL DAN PEMBAHASAN}

Kegiatan pengabdian kepada masyarakat yang telah dilakukan tentang pemanfaatan biji durian dan rambutan untuk dibuat keripik berdampak positif terhadap masyarakat, karena timbul motivasi untuk berwirausaha. Praktek pembuatan keripik dari biji durian dan rambutan tersebut sangat mudah, dan bahan dasarnya banyak tersedia di sekitar tempat tinggal masingmasing tempat pendampingan. Produk keripik yang telah diujicobakan oleh tim disajikan dengan sampel kemasan keripik biji durian (Gambar 3a) dan rambutan (Gambar 3b) sebagai upaya untuk menumbuhkan jiwa kewirausahaan ibu-ibu PKK RT03/RW03, Kelurahan Ngijo, Kecamatan Gunungpati, Semarang yang disajikan pada Gambar 3. 


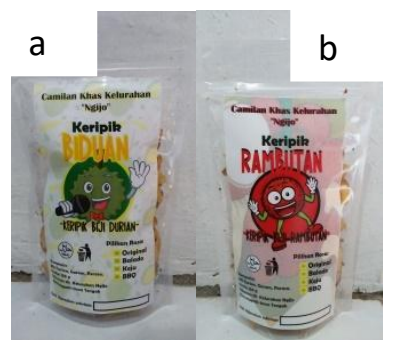

Gambar 3. Produk keripik (a) biji durian dan (b) biji rambutan

Pelaksanaan pengabdian ini berjalan dengan lancar. Hal ini bisa terlihat pada Gambar 4.

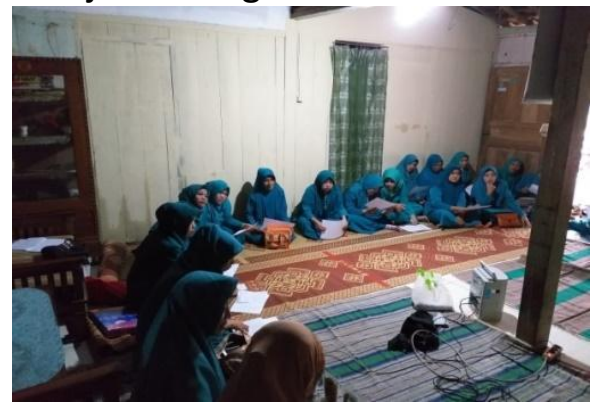

Gambar 4. Pelaksanaan pengabdian keripik biji durian dan rambutan

Gambar 4 terlihat bahwa jumlah ibu-ibu PKK memenuhi ruangan bagian dalam rumah. Sesi acara pengabdian yang didahului dengan penjelasan singkat oleh Ketua Tim dan pembagian cara kerja oleh mahasiswa tentang pembuatan keripik dari biji durian dan rambutan disajikan pada Gambar 5.

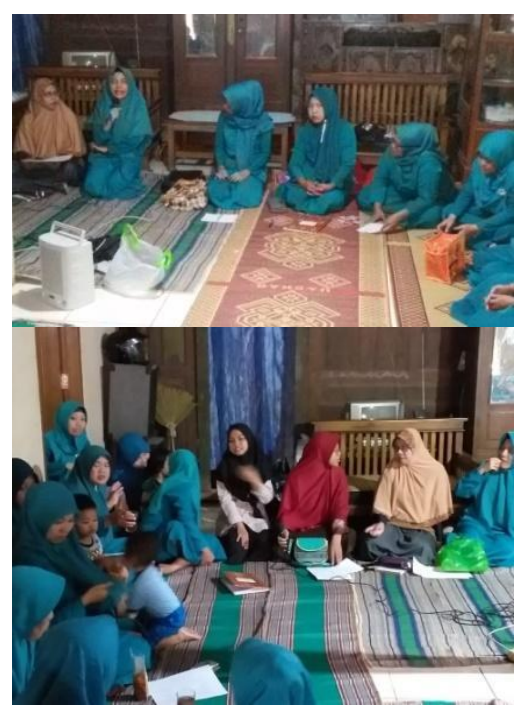

Gambar 5. Penjelasan singkat Ketua Tim dan pembagian cara kerja oleh mahasiswa

Pembagian produk keripik durian dan rambutan kepada Ibu-ibu PKK untuk dicicipi disajikan pada Gambar 6. 


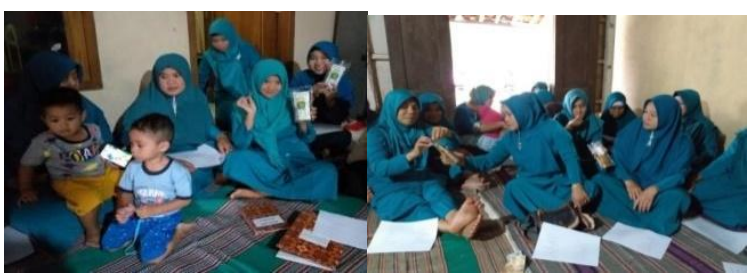

Gambar 6. Ibu-ibu PKK Mencoba keripik biji durian dan rambutan.

Setelah pembagian produk, maka antusias ibu-ibu PKK RT03/RW03, Kelurahan Ngijo, Kecamatan Gunungpati, Semarang untuk mengajukan pertanyaan terlihat dari Gambar 7.

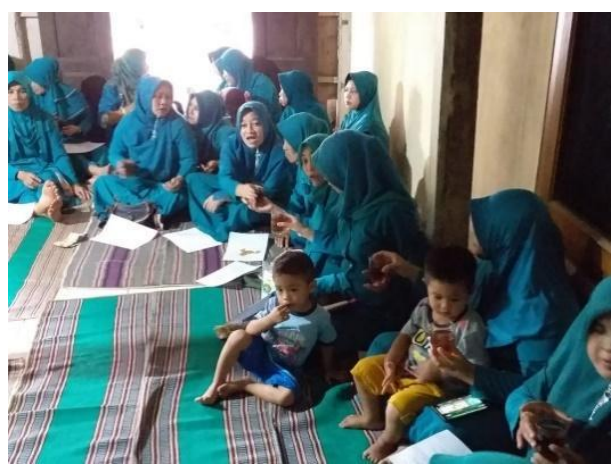

Gambar 7. Respon Ibu-ibu PKK terhadap Tim Pengabdian Keripik Biji Durian dan Rambutan.

Ibu-ibu PKK RT03/RW03 mengajukan pertanyaan tentang harga jual dan modal yang dibutuhkan untuk produksi rumahan. Kemudian tim menjawab seperti pada Gambar 8.

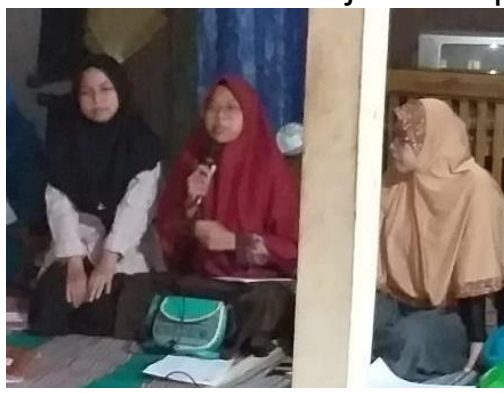

\section{Gambar 8. Tim menjawab pertanyaan}

Tim pengabdian melakukan percobaan kembali resep keripik biji durian yang telah dilakukan oleh (Kurniawati et al., 2015) dan (Widiarti et al., 2013) resep biji rambutan sebelum disosialisasikan ke masyarakat. Hasil percobaan kembali resep biji durian dan biji rambutan disajikan pada Tabel 2. dan Tabel 3. 
Tabel 2. Percobaan Keripik Biji Durian

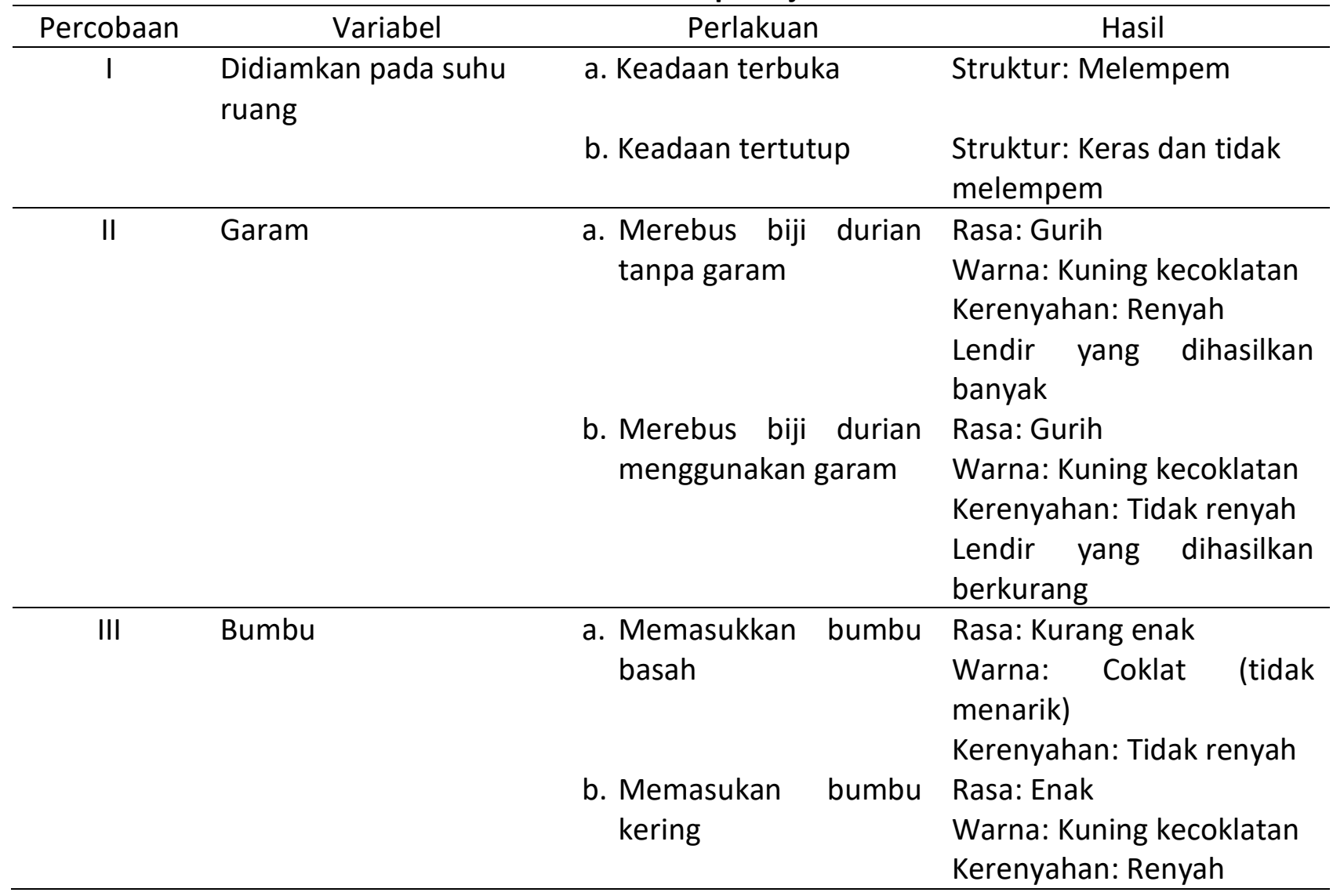

Tabel 3. Percobaan Keripik Biji Rambutan

\begin{tabular}{|c|c|c|c|}
\hline Percobaan & Variabel & Perlakuan & Hasil \\
\hline \multirow[t]{2}{*}{1} & Biji Rambutan & a. Dikeringkan sebelum penyimpanan & Biji tahan lama \\
\hline & & $\begin{array}{l}\text { b. Tanpa dikeringkan sebelum } \\
\text { penyimpanan }\end{array}$ & $\begin{array}{l}\text { Biji berjamur } \\
\text { membusuk (10 hari) }\end{array}$ \\
\hline \multirow[t]{2}{*}{ II } & Kondisi Biji & c. Biji yang masih segar & Menyatu saat digoreng \\
\hline & & d. Biji yang sudah layu & Hancur saat digoreng \\
\hline \multirow[t]{2}{*}{ III } & Penggepreka & a. Dilakukan saat masih panas & Menyatu saat digeprek \\
\hline & & b. Dilakukan saat dingin & Hancur saat di geprek \\
\hline
\end{tabular}

Tabel 2. menunjukkan bahwa setelah dilakukan percobaan sebanyak tiga kali keripik biji durian dengan hasil yang baik diperoleh dari cara merebus biji durian dan bumbu yang digunakan. Tabel 3. menunjukkan bahwa setelah dilakukan percobaan sebanyak tiga kali maka keripik biji rambutan dengan hasil yang baik diperoleh dari biji yang masih segar dan penggeprekan dilakukan saat masih panas.

Perubahan yang bisa dilihat dari ibu-ibu PKK RT03/RW03, Kelurahan Ngijo, Kecamatan Gunungpati, Semarang setelah mengikuti program pengabdian ini antara lain: 1. meningkatkan kesadaran masyarakat tentang manfaat dari biji durian dan biji rambutan 2. menumbuhkan minat 
ibu-ibu pkk untuk mengembangkan usaha pembuatan keripik dari biji durian dan biji rambutan 3. meningkatkan keterampilan ibu-ibu pkk dalam membuat keripik dari biji durian dan biji rambutan 4. keripik ini dapat sebagai alternatif keripik dari biji durian dan biji rambutan yang tadinya tidak dilirik akan potensinya.

Perubahan yang dapat dilihat dari ibu-ibu PKK RT03/RW03, Kelurahan Ngijo, Kecamatan Gunungpati, Semarang setelah mengikuti program pengabdian ini antara lain lain: 1. Meningkatkan kesadaran masyarakat tentang optimalisai buah durian dan buah rambutan sebagai produk makanan. 2. Menumbuhkan minat ibu-ibu pkk untuk mengembangkan usaha pembuatan keripik yang nantinya dapat dikembangkan sebagai home industry. 3. Meningkatkan keterampilan ibu-ibu pkk dalam membuat keripik dengan memanfaatkan biji buah durian dan rambutan. 4 . Keripik biji durian dan biji rambutan memiliki ciri khas rasa sehingga dapat meningkatkan potensi penjualan dengan target pangsa pasar yang luas.

\section{SIMPULAN DAN SARAN}

\section{Simpulan}

Berdasarkan hasil pengabdian yang telah dilakukan dapat disimpulkan bahwa di ibu-ibu PKK RT03/RW03, Kelurahan Ngijo, Kecamatan Gunungpati, Semarang sangat tertarik untuk mengembangkan wirausaha keripik biji durian dan biji rambutan.

\section{Saran}

Pendampingan masyarakat perlu dilakukan secara serius terhadap pelatihan kewirausahaan bagi ibu-ibu PKK RT03/RW03, Kelurahan Ngijo, Kecamatan Gunungpati, Semarang sebagai upaya menumbuhkan jiwa kewirausahaan. Memonitoring hasil kegiatan secara berkelanjutan untuk mengamati dan mengetahui perkembangan dan kemajuan, serta kendala permasalahan yang terjadi agar menjaga stabilitas usaha.

\section{UCAPAN TERIMA KASIH}

Kami mengucapkan terima kasih kepada Fakultas Teknik Universitas Negeri Semarang yang telah memberikan hibah PENGABDIAN KEPADA MASYARAKAT BAGI DOSEN DANA DIPA FT UNNES TAHUN 2019. Nomor: 44.22.5/UN37/PPK.4.5/2019.

\section{DAFTAR PUSTAKA}

Augustin, M. ., \& Chua, B. . (1988). Composition of rambutan seeds. Pertanika Journal of Tropical Agricultural Science, 11(2), 211-215.

Djaeni, M., \& Prasetyaningrum, A. (2010). Kelayakan buah durian sebagai bahan pangan alternatif : aspek nutrisi dan tekno ekonomi. Riptek, 4(II), 37-45.

Harmiatun, Y., Sunarto, \& Gultom, M. (2018). Pemanfaatan Limbah Biji Durian (Durio zibethinuss Murr) Sebagai Bahan Baku Pembuatan Tempe Alternatif Melalui Proses Fermentasi Oleh Jamur Rhizopus oligosporus. Jurnal Pro-Life, 5, 526-533.

Kurniawati, F., Kamsiati, E., Rukayati, \& Purwandari, S. E. (2015). Lembar Inovasi Pertanian: Pembuatan Keripik Durian.

Rosidah, Henry, A., \& Sunyoto. (2015). Pemberdayaan Masyarakat Kecamatan Gunungpati Melalui Peningkatan Produktivitas, Kualitas dan DIversifikasi Produk Pasca Panen. ABDIMAS, 19, 121-128. 
Widiarti, N., Wahyuni, S., \& Mahatmanti, F. W. (2013). Pengolahan Buah Dan Biji Rambutan Sebagai Makanan Tradisional Koktail, Manisan, Emping Biji Rambutan Dan Obat Herbal Yang Berkhasiat. Rekayasa, 11(2), 75-78. 